\title{
Characteristics of air pollution control residues of MSW incineration plant in Shanghai
}

\author{
Pin-Jing He ${ }^{\mathrm{a}, *}$, Hua Zhang ${ }^{\mathrm{a}}$, Can-Gang Zhang ${ }^{\mathrm{b}}$, Duu-Jong Lee ${ }^{\mathrm{c}}$ \\ ${ }^{a}$ State Key Laboratory of Pollution Control and Resources Reuse, Tongji University, Shanghai 200092, China \\ ${ }^{\mathrm{b}}$ Environment Protection and City Sanitation Management Bureau of Shanghai, Pudong New Area, Shanghai 200135, China \\ ${ }^{\mathrm{c}}$ Chemical Engineering Department, National Taiwan University, Taipei 10617, Taiwan
}

Received 20 December 2003; received in revised form 1 September 2004; accepted 9 September 2004

Available online 22 October 2004

\begin{abstract}
A unique type of waste - air pollution control (APC) residues - has received increasing attention in China since the first large-scale incinerator, Shanghai Yuqiao municipal solid waste (MSW) incineration plant, was installed in the country in 2002. The APC residues of this particular plant are similar to other residues that will be produced in other incineration plants under construction in China. This work examines for the first time the benchmark contaminants of APC residues from the Yuqiao Plant, with reference to soluble salts, heavy metals and dioxins. Experimental findings reveal that the residues contained a marked amount of soluble salts, of up to 17.4-21.9\% (mostly chlorides), 0.98-1.5 ng TEQ/g ash of dioxins and various heavy metals. Lead is of particular concern, and requires stabilization before disposal. Heavy metal speciation schemes were implemented herein to determine the leaching characteristics. The correlation between the amounts of soluble salts or chemical speciation of the heavy metals and the leaching toxicity of these heavy metals in the residues is considered.
\end{abstract}

(C) 2004 Elsevier B.V. All rights reserved.

Keywords: Municipal solid waste incineration; Air pollution control residues; Soluble salts; Heavy metals; Dioxins

\section{Introduction}

Air pollution control (APC) residues are formed as a by-product from municipal solid waste (MSW) incineration plants. Dioxins, heavy metals and other species are the main contaminants. These residues are often classified as hazardous wastes that require special treatment and disposal $[1,2]$. Two large-scale modern MSW incinerators were recently installed in Shanghai, each with a capacity of $1000 \mathrm{t} /$ day, together accounting for approximately $12.5 \%$ of the 16,040 t/day of MSW generated in the city [3].

MSW in Shanghai has high water content, and therefore a relatively low heat value. The installed incinerators are de-

* Corresponding author. Tel.: +86216598 1383; fax: +862165981383. E-mail address: xhpjk@mail.tongji.edu.cn (P.-J. He). signed with waste pits that store the MSW to be drained over 5 days to reduce the water content before combustion. Therefore, $165 \mathrm{t}$ of water were removed per $1000 \mathrm{t}$ of MSW received by the incinerator from October 2002 to September 2003. Accordingly, the Yuqiao MSW incineration plant, installed in the Pudong New Area of Shanghai, was able to incinerate the local MSW effectively, meeting EU emission standards and design specifications.

This study reports the characteristics of the APC residues from the Yuqiao MSW incineration plant. The levels of heavy metals, dioxins and water-soluble salts, and the correlation between these contaminants are considered. The first largescale incinerator is now being used to treat typical MSW in China, and the APC residues generated by the Yuqiao incineration plant can be regarded as representative of APC waste in China. 


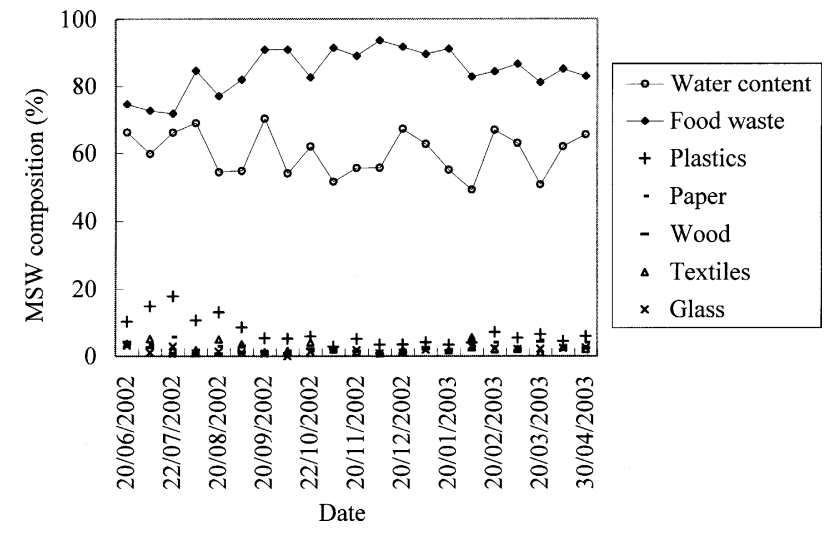

Fig. 1. The composition of MSW from Shanghai Pudong New Area.

\section{Materials and methods}

\subsection{Samples}

Fig. 1 depicts the compositions of MSW collected from the Pudong New Area of Shanghai City at a refuse transfer station from June 2002 to April 2003 [4]. Most of the solid waste is food waste; the rest of the waste includes a little paper and wood. The water content in the collected MSW reaches $50-70 \%$. The correlation analysis between the water content and the amount of food waste (sample number $(S)$ of 21 and $\alpha=0.01$, critical $r=0.549$ ) revealed no correlation (at a correlation coefficient of 0.11 ) in the received MSW.

The Yuqiao MSW incineration plant removes acid gas from the flue gas using lime slurry $(10 \%(\mathrm{w} / \mathrm{w}))$, heavy metals and dioxins using activated carbon $\left(50 \mathrm{mg} / \mathrm{m}^{3}\right)$; and particulates by bag filters (Fig. 2). The APC residues are collected from the semidry reactors and from the fabric filter.

Seven APC residues (samples 1-7) were sampled (approximately bimonthly) from Yuqiao incineration plant during May 2002-June 2003 to elucidate the seasonal variation of waste composition (Fig. 1). All samples, except for the first sample (with a $20 \%$ water content) collected after wetting to avoid fugitive dust, were of fresh ash with water content of less than $1.5 \%$.

\subsection{Analytical methods}

\subsubsection{Soluble salts}

Water-soluble salts in the ash were analyzed. The soluble salts of $\mathrm{CO}_{3}{ }^{2-}, \mathrm{Cl}^{-}$and $\mathrm{SO}_{4}{ }^{2-}$ were analyzed by extracting
$50 \mathrm{~g}$ of APC residues using decarbonated distilled water at a liquid-to-solid (L/S) ratio of 5:1, and their concentrations in the filtered extract were measured by gravimetric analysis, $\mathrm{H}^{+}$titration, $\mathrm{AgNO}_{3}$ titration and $\mathrm{BaSO}_{4}$ gravimetric analysis, respectively [5]. The concentrations of $\mathrm{Na}^{+}, \mathrm{K}^{+}$and $\mathrm{Ca}^{2+}$ were determined by atomic absorption spectrophotometer (AAS; PE5100, Perkin Elmer, USA).

\subsubsection{Heavy metals}

Ten milliliters of hydrochloric acid was added to ash sample $(0.3-0.5 \mathrm{~g})$ in a polytetrafluorethylene digestion vessel and heated on an electric heating plate until only $2-3 \mathrm{~mL}$ of hydrochloric acid remained. Then, the sample was vigorously digested with nitric acid $(5 \mathrm{~mL})$, perchloric acid $(3 \mathrm{~mL})$ and hydrofluoric acid $(5 \mathrm{~mL})$ before AAS testing [6].

\subsubsection{Leaching toxicity and chemical speciation of heavy metals}

The extraction procedure for the toxicity of solid waste (EPTSW) test and the sequential chemical extraction (SCE) test were performed herein. In the EPTSW test, $100 \mathrm{~g}$ (dry weight) of ash sample was extracted using distilled water at a $10: 1 \mathrm{~L} / \mathrm{S}$ ratio in a $2 \mathrm{~L}$ PE bottle that was shaken at $110 \pm 10 \mathrm{rpm}$ for $8 \mathrm{~h}$. After settling for $16 \mathrm{~h}$, the eluate was vacuum-filtered using a $0.45 \mu \mathrm{m}$ membrane film and the heavy metal contents in the filtrate were measured by AAS [7].

The SCE test was performed on $1 \mathrm{~g}$ of dried ash sample using the extraction sequence presented in Table 1, by a method modified from that of Kerby and Rimstidt [8], Abanades et al. [9] and Tessier et al. [10]. In each step, except the last, $10 \mathrm{~mL}$ of the specific reagent was used to extract the ash, and the extract was separated from the solid using a high speed freeze centrifuge (GL-20G-II, Anting, China) at 10,000 $\times g$ for $30 \mathrm{~min}$. The heavy metal contents in the extract were measured by AAS. In steps 1 and 4, solution $\mathrm{pH}$ was modified using nitric acid. The water-soluble or acid-soluble fractions were available for leaching under neutral or acidic conditions, respectively. The $\mathrm{Ca}$-exchangeable fraction would probably be leached out if the brine had moved through an APC residue disposal site. The Ag-exchangeable fraction was of tightly bound complexes, and was unlikely to be released by simply flowing fluids. Fractions differentiated in steps 5-8 were very hard to dissolve $[2,8,9,11]$.

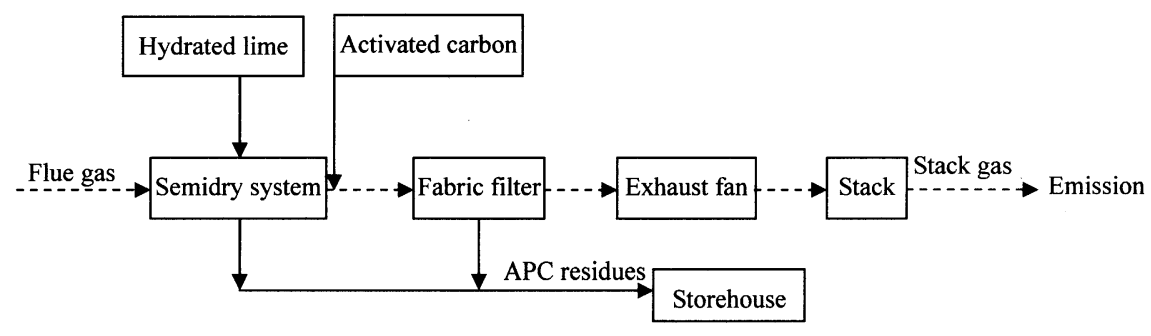

Fig. 2. Flow diagram of the APC system of Yuqiao incineration plant. 
Table 1

Sequential chemical extraction scheme for the APC residues

\begin{tabular}{|c|c|c|c|}
\hline Step & Speciation & Reagent & Conditions \\
\hline 1 & Water-soluble & Deionized water & $20^{\circ} \mathrm{C}, \mathrm{pH} 7$, continuous agitation, $3 \mathrm{~h}$ \\
\hline 2 & Ca exchangeable & $0.5 \mathrm{M} \mathrm{Ca}\left(\mathrm{NO}_{3}\right)_{2}$ & $20^{\circ} \mathrm{C}$, continuous agitation, $3 \mathrm{~h}$ \\
\hline 3 & Ag exchangeable & $0.5 \mathrm{M} \mathrm{AgNO}_{3}$ & $20^{\circ} \mathrm{C}$, continuous agitation, $3 \mathrm{~h}$ \\
\hline 4 & Acid soluble & $0.5 \mathrm{M} \mathrm{CH}_{3} \mathrm{COOH}+0.1 \mathrm{M} \mathrm{Ca}\left(\mathrm{NO}_{3}\right)_{2}$ & $20^{\circ} \mathrm{C}, \mathrm{pH} 5$, continuous agitation, $3 \mathrm{~h}$ \\
\hline 5 & Organically bound & $0.1 \mathrm{M} \mathrm{Na}_{4} \mathrm{P}_{2} \mathrm{O}_{7}$ & $85^{\circ} \mathrm{C}$, variable agitation, $3 \mathrm{~h}$ \\
\hline 6 & Amorphous iron oxide occluded & $0.175 \mathrm{M}\left(\mathrm{NH}_{4}\right)_{2} \mathrm{C}_{2} \mathrm{O}_{4}+0.1 \mathrm{M} \mathrm{H}_{2} \mathrm{C}_{2} \mathrm{O}_{4}$ & $95^{\circ} \mathrm{C}$, variable agitation, $3 \mathrm{~h}$, without light \\
\hline 7 & Crystalline iron oxide occluded & $0.1 \mathrm{M} \mathrm{Na}_{2} \mathrm{EDTA}+0.3 \mathrm{M} \mathrm{NH}_{2} \mathrm{OH} \cdot \mathrm{HC} 1$ & $95^{\circ} \mathrm{C}$, variable agitation, $24 \mathrm{~h}$ \\
\hline 8 & Residual & $10 \mathrm{~mL} \mathrm{HCl}+5 \mathrm{~mL} \mathrm{HNO}_{3}+3 \mathrm{~mL} \mathrm{HClO}_{4}+5 \mathrm{~mL} \mathrm{HF}$ & $\begin{array}{l}0.2-0.3 \mathrm{~g} \text { of dried solid ash from previous step } \\
\text { was digested }\end{array}$ \\
\hline
\end{tabular}

\subsubsection{Mineralogy}

Mineralogical analyses were performed on $20 \mathrm{~g}$ of ash using an X-ray diffractometer (XRD; PW1710, Philips, The Netherlands). The working conditions of the XRD were as follows, tube anode: $\mathrm{Cu}$; generator tension: $40 \mathrm{kV}$; generator current: $20 \mathrm{~A}$; start and end angles $(2 \theta): 3-70^{\circ}$; step size $(2 \theta)$ : $0.02^{\circ}$; time per step: $0.4 \mathrm{~s}$.

\subsubsection{Dioxins}

The dioxins, including polychlorinated dibenzo- $p$ dioxins (PCDDs), polychlorinated dibenzofurans (PCDFs) and coplanar PCBs (PCBs), in the three ash samples were analyzed by Shimadzu Techno-Research Inc., Japan. The sample was spiked with a mixture of ${ }^{13} \mathrm{C}_{12}$-labeled internal standards and then Soxhlet extracted in $300 \mathrm{~mL}$ of benzene for $16 \mathrm{~h}$. The extract was concentrated and spiked with internal standard, before being cleaned up through a multilayer silica gel column and an alumina column. The final elute was micro-concentrated and ${ }^{13} \mathrm{C}_{12}$ labeled recovery standards were added before the HRGC/HRMS procedure was performed using an HP-6890, equipped with a DB-5 MS-fused silica capillary column $(60 \mathrm{~m} \times 0.25 \mathrm{~mm} \times 0.25 \mu \mathrm{m}, \mathrm{J} \& \mathrm{~W}$ Scientific). Fig. 3 and Table 2 present the flow diagram of the analysis process and the reagents (Cambridge Isotope Laboratory Co. Ltd.) used.

\section{Results and discussion}

\subsection{Water-soluble salts}

Fig. 4 presents the results of the analysis of soluble salts. The fresh APC residues contained 17.4-21.9\% soluble salts, of which $\mathrm{Cl}^{-}$accounted for nearly half, in the form of mainly $\mathrm{NaCl}$ and $\mathrm{KCl}$, as indicated by the mineralogical analysis (Fig. 5). It also contained $1.3-1.9 \%$ of $\mathrm{SO}_{4}{ }^{2-}$ and $0.09-0.24 \%$ of $\mathrm{CO}_{3}{ }^{2-}$ (since $\mathrm{CaSO}_{4}$ and $\mathrm{CaCO}_{3}$ were detected by XRD). $\mathrm{Na}^{+}, \mathrm{K}^{+}$and $\mathrm{Ca}^{2+}$ were found to account for $35-40 \%$ of all of the soluble matter.

Soluble salts in the residues may pollute groundwater following disposal. Groundwater with more than $2000 \mathrm{mg} / \mathrm{L}$ soluble salts is classified as having the worst level of pollution, according to the "Quality standard for ground

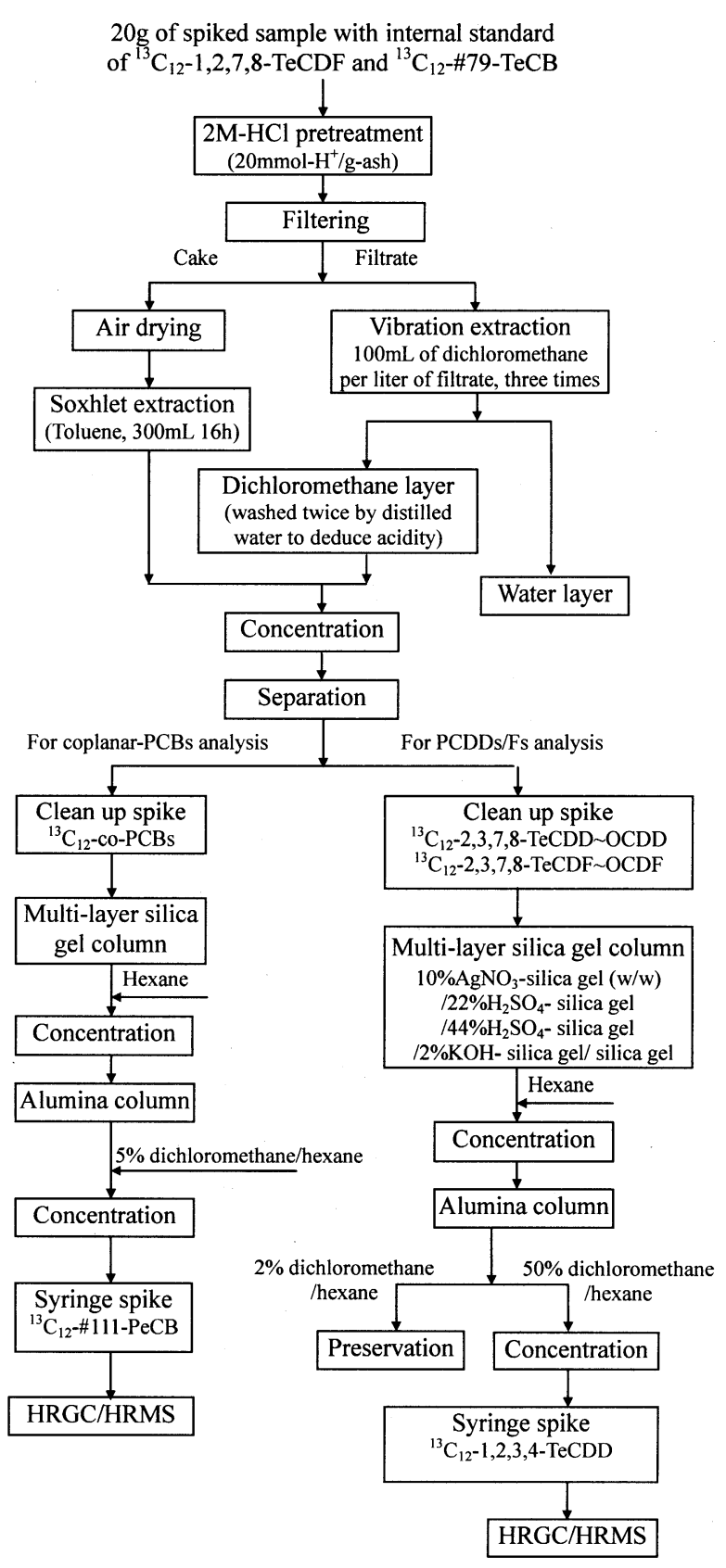

Fig. 3. Dioxin analysis of the APC residues. 
Table 2

Chemical reagents used in the dioxins measurement process

\begin{tabular}{|c|c|c|c|}
\hline Standard solution & Internal spiked standard solution & Standard solution & Internal spiked standard solution \\
\hline \multirow[t]{3}{*}{ 2,3,7,8-TeCDD } & ${ }^{13} \mathrm{C}_{12}-1,3,6,8-\mathrm{TeCDD}$ & $2,3,7,8-\mathrm{TeCDF}$ & ${ }^{13} \mathrm{C}_{12}-1,3,6,8-\mathrm{TeCDF}$ \\
\hline & ${ }^{13} \mathrm{C}_{12}-2,3,7,8-\mathrm{TeCDD}$ & & ${ }^{13} \mathrm{C}_{12}-1,2,7,8-\mathrm{TeCDF}$ \\
\hline & ${ }^{13} \mathrm{C}_{12}-1,2,3,4-\mathrm{TeCDD}$ & & ${ }^{13} \mathrm{C}_{12}-2,3,7,8-\mathrm{TeCDF}$ \\
\hline \multirow[t]{2}{*}{ 2,3,7,8-PeCDD } & ${ }^{13} \mathrm{C}_{12}-1,2,3,7,8-\mathrm{PeCDD}$ & $1,2,3,7,8-\mathrm{PeCDF}$ & ${ }^{13} \mathrm{C}_{12}-1,2,3,7,8-\mathrm{PeCDF}$ \\
\hline & & $1,2,4,7,8-\mathrm{PeCDF}$ & ${ }^{13} \mathrm{C}_{12}-1,2,4,7,8-\mathrm{PeCDF}$ \\
\hline $1,2,3,4,7,8-\mathrm{HxCDD}$ & ${ }^{13} \mathrm{C}_{12}-1,2,3,4,7,8-\mathrm{HxCDD}$ & $1,2,3,4,7,8-\mathrm{HxCDF}$ & ${ }^{13} \mathrm{C}_{12}-1,2,3,4.7,8-\mathrm{HxCDF}$ \\
\hline $1,2,3,6,7,8-\mathrm{HxCDD}$ & ${ }^{13} \mathrm{C}_{12}-1,2,3,6,7,8-\mathrm{HxCDD}$ & $1,2,3,6,7,8-\mathrm{HxCDF}$ & ${ }^{13} \mathrm{C}_{12}-1,2,3,6,7,8-\mathrm{HxCDF}$ \\
\hline \multirow[t]{2}{*}{$1,2,3,7,8,9-\mathrm{HxCDD}$} & ${ }^{13} \mathrm{C}_{12}-1,2,3,7,8,9-\mathrm{HxCDD}$ & $1,2,3,7,8,9-\mathrm{HxCDF}$ & ${ }^{13} \mathrm{C}_{12}-1,2,3,7,8,9-\mathrm{HxCDF}$ \\
\hline & & $2,3,4,6,7,8-\mathrm{HxCDF}$ & ${ }^{13} \mathrm{C}_{12}-2,3.4,6,7,8-\mathrm{HxCDF}$ \\
\hline \multirow[t]{2}{*}{ 1,2,3,4,6,7,8-HpCDD } & ${ }^{13} \mathrm{C}_{12}-1,2,3,4,6,7,8-\mathrm{HpCDD}$ & $1,2,3,4,6,7,8-\mathrm{HpCDF}$ & ${ }^{13} \mathrm{C}_{12}-1,2,3 \cdot 4,6,7,8-\mathrm{HpCDF}$ \\
\hline & & $1,2,3,4,7,8,9-\mathrm{HpCDF}$ & ${ }^{13} \mathrm{C}_{12}-1,2,3,4,7,8,9-\mathrm{HpCDF}$ \\
\hline $1,2,3,4,6,7,8,9-\mathrm{OCDD}$ & ${ }^{13} \mathrm{C}_{12}-1,2,3,4,6,7,8,9-\mathrm{OCDD}$ & $1,2,3,4,6,7,8,9-\mathrm{OCDF}$ & ${ }^{13} \mathrm{C}_{12}-1,2,3,4,6,7,8,9-\mathrm{OCDF}$ \\
\hline Standard solution & Internal standard solution & & \\
\hline$\# 813,4,4^{\prime} 5-\mathrm{TeCB}^{\mathrm{a}}$ & $\# 81^{13} \mathrm{C}_{12}-3,4,4^{\prime} 5-\mathrm{TeCB}^{\mathrm{a}}$ & & \\
\hline$\# 773,3^{\prime}, 4,4^{\prime}-\mathrm{TeCB}^{\mathrm{a}}$ & $\# 77^{13} \mathrm{C}_{12}-3,3^{\prime}, 4,4^{\prime}-\mathrm{TeCB}^{\mathrm{a}}$ & & \\
\hline$\# 1052,3,3^{\prime}, 4,4^{\prime}-\mathrm{PeCB}^{\mathrm{b}}$ & $\# 105^{13} \mathrm{C}_{12}-2,3,3^{\prime}, 4,4^{\prime}-\mathrm{PeCB}^{\mathrm{b}}$ & & \\
\hline$\# 1142,3,3^{\prime}, 4,4^{\prime}, 5^{\prime}-\mathrm{PeCB}^{\mathrm{b}}$ & $\# 114{ }^{13} \mathrm{C}_{12}-2,3,3^{\prime}, 4,4^{\prime}, 5^{\prime}-\mathrm{PeCB}^{\mathrm{b}}$ & & \\
\hline$\# 1182,3^{\prime}, 4,4^{\prime}, 5-\mathrm{PeCB}^{\mathrm{b}}$ & $\# 118^{13} \mathrm{C}_{12}-2,3^{\prime}, 4,4^{\prime}, 5-\mathrm{PeCB}^{\mathrm{b}}$ & & \\
\hline$\# 1232^{\prime}, 3,4,4^{\prime}, 5-\mathrm{PeCB}^{\mathrm{b}}$ & $\# 123{ }^{13} \mathrm{C}_{12}-2^{\prime}, 3,4,4^{\prime}, 5-\mathrm{PeCB}^{\mathrm{b}}$ & & \\
\hline$\# 1263,3^{\prime}, 4,4^{\prime}, 5-\mathrm{TeCB}^{\mathrm{a}}$ & $\# 126^{13} \mathrm{C}_{12}-3,3^{\prime}, 4,4^{\prime}, 5-\mathrm{TeCB}^{\mathrm{a}}$ & & \\
\hline$\# 1562,3,3,4,4^{\prime}, 5-\mathrm{HxCB}^{\mathrm{b}}$ & $\# 156{ }^{13} \mathrm{C}_{12}-2,3,3^{\prime}, 4,4^{\prime}, 5^{\prime}-\mathrm{HxCB}^{\mathrm{b}}$ & & \\
\hline$\# 1572,3^{\prime}, 4,4^{\prime}, 5-\mathrm{HxCB}^{\mathrm{b}}$ & $\# 157^{13} \mathrm{C}_{12}-2,3,3^{\prime}, 4,4^{\prime}, 5-\mathrm{HxCB}^{\mathrm{b}}$ & & \\
\hline$\# 1672,3,3,4,4^{\prime}, 5,5^{\prime}-\mathrm{HxCB}^{\mathrm{b}}$ & $\# 167^{13} \mathrm{C}_{12}-2,3,3^{\prime}, 4,4^{\prime}, 5,5^{\prime}-\mathrm{HxCB}^{\mathrm{b}}$ & & \\
\hline$\# 1693,3^{\prime}, 4,4^{\prime}, 5,5^{\prime}-\mathrm{HxCB}^{\mathrm{a}}$ & $\# 169^{13} \mathrm{C}_{12}-3,3^{\prime}, 4,4^{\prime}, 5,5^{\prime}-\mathrm{HxCB}^{\mathrm{b}}$ & & \\
\hline$\# 1802,2^{\prime}, 3,4,4^{\prime}, 5,5^{\prime}-\mathrm{HpCB}^{\mathrm{c}}$ & $\# 180{ }^{13} \mathrm{C}_{12}-2,2^{\prime}, 3,4,4^{\prime}, 5,5^{\prime}-\mathrm{HpCB}^{\mathrm{c}}$ & & \\
\hline$\# 1702,2^{\prime}, 3,3^{\prime}, 4,4^{\prime}, 5-\mathrm{HpCB}^{\mathrm{c}}$ & $\# 170{ }^{13} \mathrm{C}_{12}-2,2^{\prime}, 3,3^{\prime}, 4,4^{\prime}, 5-\mathrm{HpCB}^{\mathrm{c}}$ & & \\
\hline$\# 1892,3,3^{\prime}, 4,4^{\prime}, 5,5^{\prime}-\mathrm{HpCB}^{\mathrm{b}}$ & $\# 189^{13} \mathrm{C}_{12}-2,3,3^{\prime}, 4,4^{\prime}, 5,5^{\prime}-\mathrm{HpCB}^{\mathrm{b}}$ & & \\
\hline & $\# 79^{13} \mathrm{C}_{12}-3,3^{\prime}, 4,5^{\prime}-\mathrm{TeCB}^{\mathrm{b}}$ & & \\
\hline & $\# 111^{13} \mathrm{C}_{12}-2,3,3^{\prime}, 5,5-\mathrm{PeCB}^{\mathrm{b}}$ & & \\
\hline
\end{tabular}

${ }^{\text {a }}$ Non-ortho-PCBs.

b Mono-ortho-PCBs.

${ }^{c}$ Di-ortho-PCBs.

water" in China [12]. Although the "Standard for pollution control on the security landfill site for hazardous wastes" by SEPA does not state limiting concentrations of soluble salts in hazardous waste [13], France and Germany have legislated that the soluble salt content in waste in a landfill should be kept below $5 \%$ and $10 \%$, respectively [14]. These standards require that the present APC residues cannot directly be put in a landfill because of their high soluble salt contents.

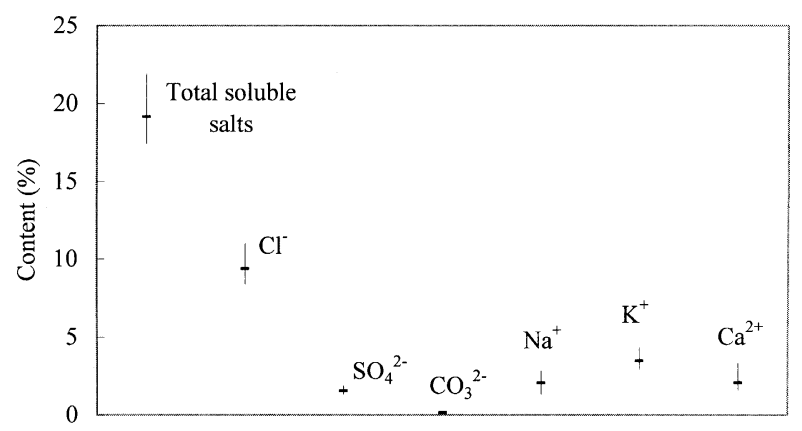

Fig. 4. Soluble salts analysis of the APC residues.

\subsection{Heavy metals}

\subsubsection{Total amount}

Table 3 states the concentration of heavy metals in the APC residues from the Yuqiao incineration plant. The $\mathrm{Cd}, \mathrm{Pb}$ and $\mathrm{Zn}$ contents in the APC residues were much lower than the range of the contents of these metals in the dry/semidry APC residues from 20 foreign Mass Burn incinerators (five in Canada, 1986-1991; four in Denmark, 1989-1992; one in Germany, 1982; one in The Netherlands, 1992; four in Sweden, 1985-1988, and five in the USA, 1988-1989) [2]. The data can be compared because similar APC systems are used in these incinerators at incineration temperatures of up to $850^{\circ} \mathrm{C}$, and the ratio of ash production to MSW by weight (4.1\% for Yuqiao incineration plant from October 2002 to 2003 and $3-5 \%$ for other incinerators stated above) is similar.

\subsubsection{Leaching toxicity of heavy metals}

Table 3 also presents the leaching characteristics of heavy metals in the APC residues and the limits set by the "Identification standard for hazardous waste" (Std A) [15] and the "Standard for pollution control at security landfill sites for hazardous waste" (Std B) [13]. The concentrations of lead of 


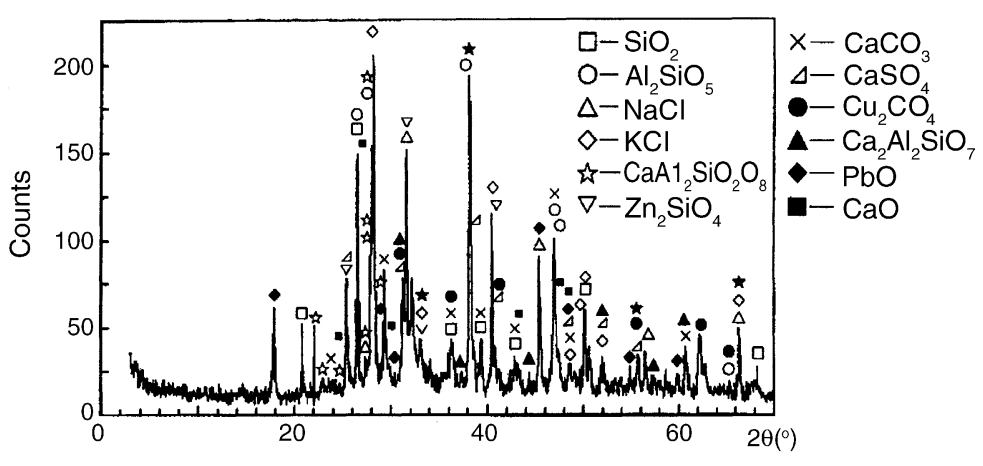

Fig. 5. XRD micrograph of the APC residues from Yuqiao incineration plant.

present APC residues greatly exceeded those limits, making the present residues hazardous waste. $\mathrm{Cd}$ and $\mathrm{Zn}$ were also heavy metals of concern.

\subsubsection{Chemical speciation}

Fig. 6 and Table 3 present the analytical results of SCE. The amounts of $\mathrm{Cd}, \mathrm{Cr}, \mathrm{Cu}$ and $\mathrm{Ni}$ leached in step 1 of SCE exceeded those in the EPTSW test, indicating that the watersoluble fractions of $\mathrm{Cd}, \mathrm{Cr}, \mathrm{Cu}$ and $\mathrm{Ni}$ contributed to the metals leached in the latter test. The leached $\mathrm{Zn}$ in the EPTSW test, however, exceeded that in step 1 of the SCE test, indicating that ion-exchangeable $\mathrm{Zn}$ was also released during the EPTSW test. This occurrence is probably attributable to the alkaline environment produced by the reaction between residue and water. All metals leached in the EPTSW tests, except for $\mathrm{Pb}$, contributed only a little to the easily leachable fractions of the total metal content (leached amounts in steps 1, 2 and 4 in the SCE test). The leached Pb in the EPTSW tests sometimes exceeded this so-defined easily leachable fraction, revealing that some $\mathrm{Pb}$ in the organically bound or crystalline iron oxide-occluded phase was also be released during the EPTSW tests (by distilled water leaching).

In the residues, Cr exhibited weak mobility because it was trapped primarily in phases that could not be easily leached (Fig. 6). In contrast, $\mathrm{Cd}, \mathrm{Cu}$ and $\mathrm{Zn}$ were far more easily leachable, and were primarily acid soluble. The $\mathrm{Pb}$ and $\mathrm{Ni}$ exhibited moderate mobility, with the former mainly acid soluble and the latter, evenly distributed in the first four leaching steps. The rich acid-soluble phase of heavy metals in the APC residues thus importantly affected their leaching characteristics.

\subsubsection{Factors that affect leaching toxicity}

The analytical results for heavy metals, presented in Table 3 and those for soluble salts presented in Fig. 4, reveal correlation coefficients $(r)$ between the amounts of heavy metals leached in EPTSW and in every step of the SCE test, which were calculated using the following equation. Correlation coefficients between soluble salts and heavy metals leached in EPTSW were also evaluated. Table 4 summarizes all results

$$
r_{i}(m, n)=\frac{\sum_{j=1}^{S}\left(H_{i, j}^{m}-\bar{H}_{i}^{m}\right)\left(H_{i, j}^{n}-\bar{H}_{i}^{n}\right)}{\left[\sum_{j=1}^{S}\left(H_{i, j}^{m}-\bar{H}_{i}^{m}\right)^{2} \sum_{j=1}^{S}\left(H_{i, j}^{n}-\bar{H}_{i}^{n}\right)^{2}\right]^{1 / 2}}
$$

where $i, j$ are the $i$ th species of heavy metal and $j$ th species of ash, respectively; $S$ the total number of the samples; $S=5$ or 7 herein; $H_{i, j}^{k}$ the amount of the $i$ th species of heavy metal (or water-soluble salt for soluble salt analysis) in the $j$ th species of ash analyzed in the $k$ th test; $\bar{H}_{i}^{k}=(1 / S) \sum_{j=1}^{S} H_{i, j}^{k}$ the average of the amount of the $i$ th species of heavy metal in the $k$ th test; $m, n, k$ the array $m$, array $n$ and array $k$, whose elements are data concerning the $S$ samples in the $m$ th, $n$th and $k$ th test (such as soluble salts analysis) or the step of SCE, array $m=\left\{H_{i, j}^{m}\right\}, n=\left\{H_{i, j}^{n}\right\}, k=\left\{H_{i, j}^{k}\right\}, j=1,2, \ldots, S ; r_{i}(m$, $n$ ) the correlation coefficient between array $m$ and array $n$.

The amount of heavy metals leached in EPTSW correlated with the amount of water-soluble phase more strongly than

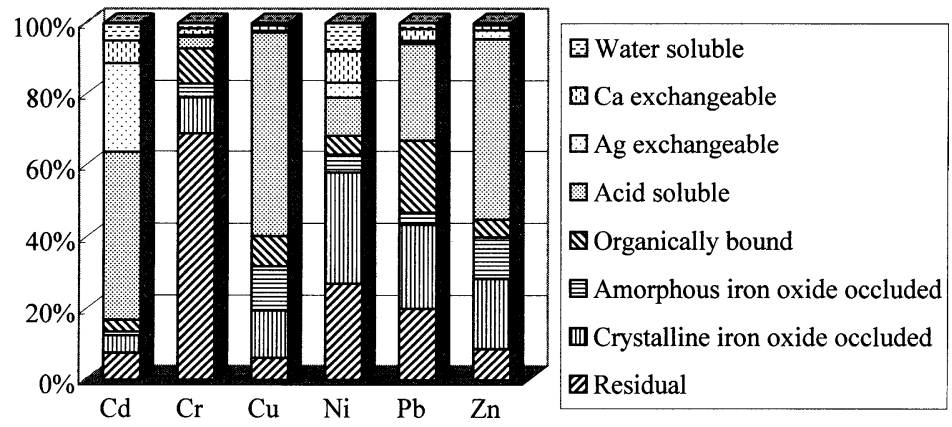

Fig. 6. Results of SCE of the APC residues (sampled on October 2002). 
Table 3

Analytical results of heavy metals

\begin{tabular}{|c|c|c|c|c|c|c|c|c|}
\hline & \multicolumn{7}{|l|}{ Sample } & \multirow[t]{2}{*}{ Remark (over } \\
\hline & 1 (May) & 2 (September) & 3 (November) & 4 (January) & 5 (April) & 6 (May) & 7 (June) & \\
\hline \multicolumn{9}{|c|}{ Total content (detected after digestion) $(\mathrm{mg} / \mathrm{kg})$} \\
\hline $\mathrm{Cd}$ & 49.8 & 65.8 & 44.9 & 52.7 & 50.9 & NA & NA & $140-300$ \\
\hline $\mathrm{Cr}$ & 350 & 322 & 329 & 335 & 255 & NA & NA & $73-570$ \\
\hline $\mathrm{Cu}$ & 770 & 667 & 561 & 628 & 665 & NA & NA & $16-1700$ \\
\hline $\mathrm{Ni}$ & 136 & 131 & 88.1 & 115 & 134 & NA & NA & $19-710$ \\
\hline $\mathrm{Pb}$ & 2480 & 1620 & 972 & 1230 & 2130 & NA & NA & $2500-10000$ \\
\hline $\mathrm{Zn}$ & 3610 & 4860 & 3650 & 4160 & 4940 & NA & NA & 7000-20000 \\
\hline
\end{tabular}

Leaching toxicity (EPTSW) $(\mathrm{mg} / \mathrm{L})$

$\begin{array}{llllllllll}\mathrm{Cd} & 0.07 & 0.17 & 0.12 & 0.14 & 0.13 & 0.20 & 0.19 & 0.3^{\mathrm{a}} & 0.5^{\mathrm{b}} \\ \mathrm{Cr} & 0.14 & 0.24 & 0.60 & 0.08 & 0.11 & 0.15 & 0.12 & 10^{\mathrm{a}} & 12^{\mathrm{b}} \\ \mathrm{Cu} & 0.13 & 0.19 & 0.12 & 0.14 & 0.11 & 0.32 & 0.43 & 50^{\mathrm{a}} & 75^{\mathrm{b}} \\ \mathrm{Ni} & 0.28 & 0.63 & 0.53 & 0.49 & 0.44 & 0.47 & 0.46 & 10^{\mathrm{a}} & 15^{\mathrm{b}} \\ \mathrm{Pb} & 6.88 & 88.1 & 27.6 & 53.7 & 92.5 & 98.8 & 63.2 & 3^{\mathrm{a}} & 5^{\mathrm{b}} \\ \mathrm{Zn} & 0.11 & 7.11 & 3.73 & 0.70 & 4.57 & 5.42 & 5.04 & 50^{\mathrm{a}} & 75^{\mathrm{b}}\end{array}$

Leached metals in step 1 (water-soluble phase, SCE) $(\mathrm{mg} / \mathrm{kg})$

$\begin{array}{lccccccc}\mathrm{Cd} & 6.04 & 2.78 & 8.73 & 1.70 & 9.43 & 28.2 & 55.7 \\ \mathrm{Cr} & 4.95 & 3.55 & 6.20 & 2.04 & 2.89 & 3.84 & 2.76 \\ \mathrm{Cu} & 3.51 & 3.78 & 1.83 & 1.69 & 2.73 & 5.78 & 6.72 \\ \mathrm{Ni} & 8.21 & 9.24 & 8.13 & 6.17 & 9.31 & 8.10 & 10.8 \\ \mathrm{~Pb} & 15.9 & 27.9 & 17.6 & 16.9 & 26.8 & 27.4 & 26.4 \\ \mathrm{Zn} & 3.40 & 16.6 & 5.90 & 4.24 & 6.16 & 132 & 216\end{array}$

Leached metals in step 2 (Ca exchangeable phase, SCE) $(\mathrm{mg} / \mathrm{kg})$

\begin{tabular}{|c|c|c|c|c|c|c|c|}
\hline $\mathrm{Cd}$ & 4.14 & 3.61 & 2.63 & 2.76 & 3.03 & 2.74 & 2.64 \\
\hline $\mathrm{Cr}$ & 4.35 & 4.81 & 5.01 & 3.38 & 4.02 & 5.39 & \\
\hline $\mathrm{Cu}$ & 3.05 & 9.31 & 2.40 & 4.65 & 4.06 & 4.30 & \\
\hline $\mathrm{Ni}$ & 11.9 & 10.5 & 11.7 & 9.65 & 9.78 & 7.78 & \\
\hline $\mathrm{Pb}$ & 35.0 & 57.3 & 23.5 & 40.4 & 44.6 & 36.1 & 50.0 \\
\hline $\mathrm{Zn}$ & 4.57 & 51.2 & 8.60 & 14.1 & 11.5 & 16.0 & 160 \\
\hline \multicolumn{8}{|c|}{ eached metals in step 3 (Ag exchangeable phase, $\mathrm{SCE})(\mathrm{mg} / \mathrm{kg})$} \\
\hline $\mathrm{Cd}$ & 19.8 & 14.4 & 12.2 & 20.4 & 14.7 & 25.9 & \\
\hline $\mathrm{Cr}$ & 1.15 & 1.23 & 1.33 & 0.50 & 0.85 & 1.19 & \\
\hline $\mathrm{Cu}$ & 3.27 & 2.06 & 1.47 & 1.62 & 3.23 & 3.95 & \\
\hline $\mathrm{Ni}$ & 6.66 & 5.15 & 4.60 & 3.95 & 4.74 & 4.52 & \\
\hline $\mathrm{Pb}$ & 11.8 & 15.4 & 10.7 & 17.5 & 24.2 & 22.1 & \\
\hline $\mathrm{Zn}$ & 286 & 101 & 132 & 142 & 307 & 369 & 430 \\
\hline
\end{tabular}

Leached metals in step 4 (acid soluble phase, SCE) (mg/kg)

$\begin{array}{lccccccc}\mathrm{Cd} & 18.7 & 26.9 & 7.57 & 14.6 & 8.81 & 21.3 & 18.8 \\ \mathrm{Cr} & 16.3 & 8.38 & 3.30 & 0.56 & 1.38 & 1.56 & 3.85 \\ \mathrm{Cu} & 339 & 351 & 134 & 82.0 & 157 & 177 & 395 \\ \mathrm{Ni} & 12.3 & 12.7 & 5.74 & 7.54 & 7.41 & 10.0 & 10.2 \\ \mathrm{~Pb} & 507 & 482 & 239 & 257 & 511 & 400 & 868 \\ \mathrm{Zn} & 1190 & 1950 & 627 & 541 & 830 & 1090 & 1640\end{array}$

Leached metals in step 5 (Organically bound phase, SCE) $(\mathrm{mg} / \mathrm{kg})$

$\begin{array}{lccccccc}\mathrm{Cd} & 2.68 & 1.90 & 1.70 & 2.45 & 1.64 & 2.16 & 1.55 \\ \mathrm{Cr} & 15.9 & 25.2 & 29.1 & 11.7 & 10.8 & 6.06 & 7.13 \\ \mathrm{Cu} & 69.9 & 52.7 & 105 & 125 & 67.8 & 84.9 & 68.4 \\ \mathrm{Ni} & 5.79 & 6.30 & 6.33 & 5.43 & 5.15 & 5.86 & 6.43 \\ \mathrm{~Pb} & 473 & 356 & 233 & 314 & 367 & 353 & 397 \\ \mathrm{Zn} & 151 & 190 & 225 & 265 & 139 & 251 & 147\end{array}$

Leaehed metals in step 6 (Amorphous iron oxide occluded phase, SCE) (mg/kg)

$\begin{array}{lccccccc}\mathrm{Cd} & 0.77 & 0.58 & 0.40 & 0.78 & 0.54 & 0.82 & 0.66 \\ \mathrm{Cr} & 10.0 & 10.1 & 0.00 & 21.8 & 18.9 & 17.5 & 19.5 \\ \mathrm{Cu} & 56.9 & 75.5 & 97.0 & 202 & 173 & 269 & 156 \\ \mathrm{Ni} & 7.57 & 5.90 & 5.67 & 7.17 & 6.03 & 8.49 & 7.43 \\ \mathrm{~Pb} & 69.4 & 58.8 & 50.8 & 48.0 & 105 & 126 & 110 \\ \mathrm{Zn} & 322 & 446 & 416 & 446 & 643 & 756 & 468\end{array}$


Table 3 (Continued)

\begin{tabular}{|c|c|c|c|c|c|c|c|c|}
\hline & \multicolumn{7}{|l|}{ Sample } & \multirow[t]{2}{*}{ Remark (overseas incinerators) } \\
\hline & 1 (May) & 2 (September) & 3 (November) & 4 (January) & 5 (April) & 6 (May) & 7 (June) & \\
\hline \multicolumn{9}{|c|}{ Leached metals in step 7 (Crystalline iron oxide occluded phase, SCE) (mg/kg) } \\
\hline $\mathrm{Cd}$ & 4.52 & 2.81 & 1.13 & 8.56 & 8.17 & 11.6 & 5.56 & \\
\hline $\mathrm{Cr}$ & 38.5 & 25.9 & 0.00 & 41.9 & 87.5 & 68.0 & 47.3 & \\
\hline $\mathrm{Cu}$ & 132 & 82.1 & 201 & 153 & 236 & 336 & 229 & \\
\hline $\mathrm{Ni}$ & 38.6 & 37.1 & 29.4 & 36.8 & 60.6 & 86.2 & 69.7 & \\
\hline $\mathrm{Pb}$ & 501 & 416 & 1230 & 1650 & 2350 & 2180 & 1330 & \\
\hline $\mathrm{Zn}$ & 990 & 773 & 1810 & 1430 & 2290 & 2840 & 2150 & \\
\hline \multicolumn{9}{|c|}{ Leached metals in step 8 (Residual phase, SCE) (mg/kg) } \\
\hline $\mathrm{Cd}$ & 15.9 & 4.48 & 6.52 & 6.02 & 5.19 & 5.71 & 6.56 & \\
\hline $\mathrm{Cr}$ & 469 & 177 & 272 & 216 & 242 & 175 & 188 & \\
\hline $\mathrm{Cu}$ & 156 & 39.0 & 74.3 & 59.2 & 104 & 74.2 & 82.1 & \\
\hline $\mathrm{Ni}$ & 106 & 34.5 & 38.8 & 53.2 & 71.6 & 153 & 211 & \\
\hline $\mathrm{Pb}$ & 1010 & 357 & 762 & 852 & 1960 & 839 & 688 & \\
\hline $\mathrm{Zn}$ & 1690 & 339 & 919 & 825 & 1360 & 1130 & 1060 & \\
\hline
\end{tabular}

a Std A.

b Std B.

with that of the acid-soluble phase, because the extractant was distilled water. (The $\mathrm{pH}$ values of the leachants exceeded 12 at the end of the extraction.) The amounts of $\mathrm{Pb}$ and $\mathrm{Cu}$ were positively correlated with the amounts of water-soluble salts. However, the contribution of heavy metals in the other seven phases was not clearly correlated with their leaching capacity (Table 4).

The teachability of $\mathrm{Cd}, \mathrm{Ni}$ and $\mathrm{Pb}$ was found to be affected by the soluble salts in the residues, especially $\mathrm{Cl}^{-}$, perhaps because the $\mathrm{HC} 1$ generated during incineration was released into the flue gas and finally intercepted in the APC residues, hence affecting the speciation of heavy metals.

\subsection{Dioxins}

Samples of the APC residues for dioxin analysis were collected in January, May and June 2003. The corresponding MSW compositions and water contents varied noticeably. For example, the leachate pumped from the waste pit was $0.07 \mathrm{t} / \mathrm{t}$ of MSW in January but as high as $0.22 \mathrm{t} / \mathrm{t}$ of MSW in the sum- mer. For the first time, the dioxin level in the APC residues from China was measured (Table 5). The concentrations of dioxins ranged from $0.98 \mathrm{ng} \mathrm{TEQ} / \mathrm{g}$ ash in the January sample to $1.5 \mathrm{ng} \mathrm{TEQ} / \mathrm{g}$ ash in the May sample. The concentration of dioxins apparently increased with the amounts of plastic and water in the collected MSW.

The dioxin contents were in a similar range to those of the APC residues from some overseas incinerators (Table 6) [16-25]. Although the composition of MSW in Shanghai differs from that of refuse in other parts of the world, the dioxin level in the APC residues was only slightly different.

Current regulations in China, such as the "Environmental quality standard for soils" [26] or the "Standard for pollution control at secure landfill sites for hazardous wastes" [13], do not control dioxin concentrations. The APC residues examined herein do not comply with the environmental quality standards for soil applications ( $<1 \mathrm{ng} \mathrm{TEQ} / \mathrm{g}$ ash) that are specified by the "Law concerning special measures against dioxin" in Japan [27]. However, the levels are acceptable for landfill ( $<3 \mathrm{ng} \mathrm{TEQ} / \mathrm{g}$ ash [27]).

Table 4

Correlation coefficients $r$ between heavy metals leached in EPTSW (array $m$ ) and array $n$

\begin{tabular}{|c|c|c|c|c|c|c|}
\hline Array $n$ & $\mathrm{Cd}$ & $\mathrm{Cr}$ & $\mathrm{Cu}$ & $\mathrm{Ni}$ & $\mathrm{Pb}$ & $\mathrm{Zn}$ \\
\hline Water-soluble (SCE) & 0.591 & 0.811 & 0.902 & 0.072 & 0.881 & 0.337 \\
\hline Ca exchangeable (SCE) & -0.586 & 0.418 & 0.126 & -0.165 & 0.688 & 0.724 \\
\hline Ag exchangeable (SCE) & 0.366 & 0.636 & 0.802 & -0.546 & 0.754 & 0.031 \\
\hline Acid soluble (SCE) & 0.412 & 0.000 & 0.566 & -0.146 & 0.231 & 0.641 \\
\hline Organically bound (SCE) & -0.515 & 0.826 & -0.291 & 0.376 & -0.107 & -0.222 \\
\hline Amorphous iron oxide occluded (SCE) & 0.098 & -0.904 & 0.291 & -0.498 & 0.456 & 0.365 \\
\hline Crystalline iron oxide occluded (SCE) & 0.371 & -0.764 & 0.362 & -0.126 & 0.462 & 0.163 \\
\hline Residual (SCE) & -0.770 & 0.077 & -0.204 & -0.378 & 0.175 & -0.577 \\
\hline Total (detected after digestion) & 0.663 & 0.195 & 0.091 & 0.359 & 0.040 & 0.702 \\
\hline Total soluble salts & 0.970 & 0.227 & 0.537 & 0.948 & 0.815 & 0.855 \\
\hline $\mathrm{Cl}^{-}$ & 0.986 & 0.043 & 0.618 & 0.912 & 0.887 & 0.837 \\
\hline $\mathrm{SO}_{4}{ }^{2-}$ & 0.596 & 0.783 & 0.114 & 0.787 & 0.196 & 0.490 \\
\hline
\end{tabular}

When $S=7$ and $\alpha=0.01, r_{\mathrm{c}}$ (critical $r$ ) $=0.874$, and if $r>r_{\mathrm{c}}$, the two arrays are the so-called obviously correlated. 
Table 5

Dioxin contents of the APC residues from Shanghai Yuqiao incineration plant

\begin{tabular}{lcc}
\hline Time & Sample 4 (January) & Sample 6 (end of May) \\
\hline Measured content & & Sample 7 (start of June) \\
PCDDs (ng/g) & 11 & 28 \\
PCDFs (ng/g) & 30 & 45 \\
PCDDs/Fs (ng/g) & 41 & 73 \\
PCDDs/Fs (ng TEQ/g) & 0.97 & 1.5 \\
TEQ & & 56 \\
PCBs (ng TEQ/g) & 0.013 & 0.023 \\
Total (ng TEQ/g) & 0.98 & 1.5 \\
Discharged leachate/MSW (wt.\%) & 6.60 & 21.8 \\
\hline
\end{tabular}

Table 6

Dioxin contents of APC residues from overseas MSW incinerators

\begin{tabular}{|c|c|c|c|c|c|c|}
\hline & Denmark & & UK & Spain & Korea & EU \\
\hline Incinerators (number) & 19 & & 11 & 8 & 11 & Newly installed \\
\hline References & [16] & & {$[17]$} & {$[18]$} & [19] & {$[20]$} \\
\hline \multirow[t]{2}{*}{ Dioxins (ng TEQ/g) } & $0.1-3.8$ & & $0.033-5.80$ & $0.07-3.5$ & $0.13-21$ & $0.81-1.8$ \\
\hline & \multicolumn{4}{|l|}{ Japan } & \multicolumn{2}{|l|}{ Taiwan } \\
\hline Incinerators (number) & 1 & 3 & 4 & 1 & 4 (>900 t/day) & $2(<150 \mathrm{t} /$ day $)$ \\
\hline References & {$[21]$} & {$[22]$} & {$[23]$} & {$[24]$} & {$[25]$} & {$[25]$} \\
\hline Dioxins (ng TEQ/g) & 2.63 & $7.3-641$ & $0.5-6.7$ & 0.65 & $0.26-6.95$ & $23.8,28.9$ \\
\hline
\end{tabular}

\subsection{Managing APC residues in Pudong New Area}

The amounts of contaminants in APC residues depend on the characteristics of MSW, the incineration temperature and the removal efficiency of the APC system. Further works on the effect of characteristics of MSW (including some minor constituents such as used batteries) on those of APC residues were undertaken in the authors' laboratory. In Shanghai, used batteries have been recovered for 5 years, and efforts in this area continue to be made. A policy will soon be implemented in Shanghai to charge for plastic bags in supermarkets to control their use. The effect of these management measures on the polluting characteristics of APC residues will gradually become evident.

As stated above, $\mathrm{Pb}, \mathrm{Cd}$ and $\mathrm{Zn}$ are the heavy metals of concern in APC residues. In particular, the level of Pb substantially exceeded the permitted level of leaching toxicity for landfill. The residues also contained considerable amounts of soluble salts, with a strong potential to pollute groundwater after landfill. Accordingly, heavy metals in APC residues should be stabilized and soluble salts should be flushed out before final disposal. The state-of-the-art MSW management practice in the Pudong New Area of Shanghai comprises an incineration plant, a recycling facility and a sanitary landfill site. The City Government plans to construct a second landfill site. Available heavy metals may be released when water flows through APC residues, so the use of a mono-landfill unit for APC residues, with a cover, is more suitable than the use of co-landfill with MSW, because the food waste in the latter generates a very large amount of leachate to promote metal leaching.

\section{Conclusions}

The contaminant characteristics of air pollution control (APC) residues of the first large-scale municipal solid waste (MSW) incinerator in China, located in the Pudong New Area of Shanghai, were investigated in this work. The distributions of heavy metals in the APC residues examined herein differed notably from those from other overseas incinerators: lead $(\mathrm{Pb})$ was the heavy metal that made the residues hazardous waste. The leaching toxicity of heavy metals (except $\mathrm{Pb}$ ) extracted by the extraction procedure for toxicity of solid waste (EPTSW) test depended primarily on the content in the water-soluble and acid-soluble phase, as determined in sequential chemical extraction (SCE) tests. However, the $\mathrm{Pb}$ leached in the EPTSW tests was in a more tightly bound form.

The APC residues contained substantial amounts of soluble salts, primarily $\mathrm{Cl}^{-}$, whose concentrations were related to the leaching toxicity of the heavy metals. The total amount of soluble salts also exceeded the amounts in the regulations set in various countries for landfill.

The content of dioxins in the APC residues herein was related to the data collected at similar incinerators worldwide, ranging from 0.98 to $1.5 \mathrm{ng} \mathrm{TEQ} / \mathrm{g}$ ash. These values were not consistent with the environmental quality standard for soils ( $<1 \mathrm{ng} \mathrm{TEQ} / \mathrm{g}$ ash) but were acceptable for a landfill site ( $<3 \mathrm{ng} \mathrm{TEQ} / \mathrm{g}$ ash), according to Japanese regulations. Accordingly, the residues were proposed to be disposed of in a dedicated mono-landfill unit, with a pollution control system, following stabilization of the heavy metals and flushing out of the soluble salts. 


\section{Acknowledgments}

We thank Shanghai Council of Science and Technology, China Ministry of Construction, and Shanghai Municipal Government for their financial support through the project "Research on beneficial use of MSW incineration residues and its demonstration project" (032312043), "Characterization and beneficial use of MSW incineration residues" (03-2-051), and the Key Subject Project, respectively. We appreciate Shimadzu Techno-research Co. for their measurement of dioxins in APC residue. We are also grateful to Shanghai Yuqiao incineration plant for their kind help for sampling collection and providing field data.

\section{References}

[1] N. Alba, S. Gasso, T. Lacorte, J.M. Baldasano, Characterization of municipal solid waste incineration residues from facilities with different air pollution control systems, JAWMA 47 (11) (1997) 1170-1179.

[2] A.J. Chandler, T.T. Eighmy, J. Hartlén, O. Hjelmar, D.S. Kosson, S.E. Sawell, H.A. van der Sloot, J. Vehlow, Municipal Solid Waste Incinerator Residues, Elsevier, The Netherlands, 1997, pp. 450-472, 583.

[3] Shanghai Environmental Protection Bureau (SEPB). Shanghai Environmental Bulletin, 2003. http://www.sepb.gov.cn/english/2003.htm.

[4] Shanghai Environmental Engineering Design and Research Institute. Report to Pudong New Area Waste Management Bureau: MSW composition in Pudong New Area during June 2002 to April 2003, 2003.

[5] State Environmental Protection Administration of China, Analysis methods of water-soluble salt for forest soil, GB 7871-87, 1987.

[6] L.Q. Zhao, P.J. He, H. Zhang, Determination and optimization of digestion methods for municipal solid waste incinerator residues, Shanghai Environ. Sci. 22 (2) (2003) 47-50.

[7] State Environmental Protection Administration of China, Solid waste - extraction procedure for toxicity of solid waste - horizontal vibration method, GB5086.2-1997, 1997.

[8] C.S. Kerby, J.D. Rimstidt, Mineralogy and surface properties of municipal solid waste ash, Environ. Sci. Technol. 27 (4) (1993) 652-660.

[9] S. Abanades, G. Flamant, B. Gagnepain, D. Gauthier, Fate of heavy metals during municipal solid waste incineration, Waste Manage. Res. 20 (1) (2000) 55-68.

[10] A. Tessier, P.G.C. Campbell, M. Bisson, Sequential extraction procedure for the speciation of particulate trace metals, Anal. Chem. 51 (7) (1979) 844-851.
[11] M. Takaoka, Y. Kuramoto, N. Takeda, T. Fujiwara, Speciation of zinc, lead and copper on fly ash by X-ray photoelectron spectroscopy, J. Jpn. Waste Soc. 12 (3) (2001) 102-111.

[12] State Environmental Protection Administration of China, Quality standard for ground water, GB/T14848-93, 1993.

[13] State Environmental Protection Administration of China, Standard for pollution control on the security landfill site for hazardous wastes, GB 18598-2001, 2001.

[14] Z. Abbas, A.P. Moghaddam, B.M. Steenari, Release of salts from municipal solid waste combustion residues, Waste Manage. 23 (2003) 291-305.

[15] State Environmental Protection Administration of China, Identification standard for hazardous wastes-identification for extraction procedure toxicity, GB5085.3-1996, 1996.

[16] Danish Environmental Protection Agency, Dioxins—sources, levels and exposures in Denmark, 1997. http://www.chem.unep.ch/pops/ DENDIOX.html.

[17] Environmental Agency of UK, Solid residues from municipal waste incinerators in England and Wales, 2002. http://www.environmentagency.gov.uk/commondata/105385/ash_pdf4.pdf.

[18] B. Fabrellas, P. Sanz, E. Abad, J. Rivera, The Spanish dioxin inventory: proposal and preliminary results from municipal waste incinerator emissions, Organohal. Compounds 41 (1999) 491-494.

[19] K.J. Shin, Y.S. Chang, Characterization of polychlorinated dibenzop-dioxins dibenzofurans, biphenyls, and heavy metals in fly ash produced from Korean municipal solid waste incinerators, Chemosphere 38 (11) (1999) 2655-2666.

[20] AEA Technology, Releases of dioxins and furans to land and water in Europe, Report produced for Landesumweltamt NordrheinWestfalen, Germany, EPSC/20591001/R003, 1999. http://europa.eu. int/comm/environment/dioxin/stage2/dioxins_to_land_and_water.pdf.

[21] M. Osako, Y.J. Kim, D.H. Lee, A pilot and field investigation on mobility of PCDDs/PCDFs in landfill site with municipal solid waste incineration residue, Chemosphere 48 (2002) 849-856.

[22] S. Kumagai, S. Koda, T. Miyakita, Estimation of dioxin exposure concentrations and dioxin intakes of workers at continuously burning municipal waste incinerators, J. Occup. Health 43 (2) (2001) 61-69.

[23] Japan Synchrotron Radiation Research Institute, Direct speciation of copper, lead, antimony, zinc and chromium in municipal solid waste incinerator fly ash by X-ray absorption fine structure spectroscopy, In SPring-8 Research Frontiers 2000-2001, http://www.spring8.or.jp/e/publication/res_fro/RF00-01/065-067.pdf.

[24] H. Katsuura, T. Inoue, M. Hiraoka, S. Sakai, Full-scale plant study on fly ash treatment by the acid extraction procedure, Waste Manage. $16(5 / 6)(1996)$ 491-499.

[25] Y.C. Ling, C.C. Hon Peter, A Taiwanese study of 2,3,7,8-substituted PCDD/DFs and coplanar PCBs in fly ashes from incinerators, J. Hazard. Mater. 58 (1998) 83-91.

[26] State Environmental Protection Administration of China, Environmental quality standard for soils, GB15618-1995, 1995.

[27] Ministry of the Environment, Informational brochure dioxins 2001, Japan. http://www.env.go.jp/en/topic/dioxin/brochure2001.pdf. 